\title{
Nota / Note \\ FIELD COMPARISON BETWEEN SELECTION METHODS AT THE MAIZE SEEDLING STAGE IN RELATION TO ALUMINUM TOLERANCE
}

\author{
Carlos Daniel Giaveno1; José Branco de Miranda Filho²* \\ ${ }^{1}$ Pós-Graduando em Genética e Melhoramento de Plantas - USP/ESALQ. \\ ${ }^{2}$ Departamento de Genética - USP/ESALQ, C.P. 83 - CEP: 13418-900 - Piracicaba, SP. \\ *Corresponding author <jbmirand@carpa.ciagri.usp.br>
}

ABSTRACT: Selection and breeding for aluminum tolerance is a useful approach to increase maize (Zea mays L.) grain yield in acid soils. The objective of this work was the comparison between two screening approaches for the development of Al tolerant maize populations. One cycle of divergent selection for aluminum tolerance, using both nutrient solution and pots with acid soil, were completed in the maize population SIKALQ. The four sub-populations selected through both selection procedures were compared with the original population and checks in field trials repeated over locations. Eight environments stratified into four groups varying from non acid to high aluminum saturation were used. Three variables were analyzed for comparisons of methodologies: grain yield, plant height and days to male flowering. The populations performed similarly in the high productivity locations and the differences between tolerant and sensitive ones were more evident for increasing levels of toxic aluminum. In spite of little differences, selection in pots with acid soil was more efficient than nutrient solution in changing the genetic structure of the population toward more tolerant and sensitive levels.

Key words: Zea mays, acid soils, seedling, divergent selection

\section{MÉTODOS DE SELEÇÃO DE PLÂNTULAS DE MILHO NO CAMPO EM RELAÇÃO À TOLERÂNCIA AO ALUMÍNIO}

\begin{abstract}
RESUMO: A seleção e o melhoramento visando tolerância ao alumínio é um procedimento valioso para aumentar a produção de milho (Zea mays L.) em solos ácidos. O objetivo deste trabalho foi comparar a eficiência de duas metodologias de seleção de plântulas, no desenvolvimento de populações de milho tolerantes ao alumínio. Foi realizado na população SIKALQ, um ciclo de seleção divergente para tolerância ao alumínio, utilizando solução nutritiva e vasos com solo ácido. As quatro sub-populações selecionadas pelas duas metodologias foram comparadas com a população original e testemunhas em experimentos de campo em vários locais. Foram utilizados oito locais, estratificados em quatro grupos começando com solos não ácidos até com alta saturação com alumínio. As comparações foram realizadas utilizando três variáveis: produção de grãos, altura de planta e dias até florescimento. As populações apresentaram um comportamento semelhante entre elas nos locais de alta produtividade, e as diferenças entre as tolerantes e suscetíveis ficaram mais evidentes na medida em que aumentou a toxidez por alumínio. Os resultados sugerem que a seleção em vasos com solo ácido foi mais eficiente em alterar a estrutura genética da população do que a solução nutritiva.
\end{abstract}

Palavras-chave: Zea mays, solos ácidos, plântulas, seleção divergente

\section{INTRODUCTION}

Acid soils reduce plant yield through deficiencies of most nutrients, as phosphorous, calcium and nitrogen, or by toxicity of aluminum and manganese (Moro, 1995). Aluminum toxicity is the major factor limiting plant growth on acid soils. Acid soils comprise large agricultural areas mainly in tropical and subtropical regions (Kochian, 1995). Near eight million hectares of maize are cultivated under acidic conditions (Pandey et al., 1994).

Genetic improvement was proved to be a useful approach to increase maize yield in acid soils because the selection for aluminum tolerance can be performed provided that genetic variability is available. Field trials were extensively used for evaluating tolerance in acid soils, but this strategy proved to be very expensive besides the fact that results are highly unstable due to the natural variability of soils and climatic conditions. To avoid these problems, some approaches in controlled environment were proposed. Several approaches for screening genotypes have been employed: pots with acid soils (Ahlrichs et al., 1990; Urrea Gomez et al., 1996), culture in nutrient solutions (Magnavaca et al.,1987; Lima et al., 1992; Giaveno et al., 1998), staining techniques using chemicals as hematoxilyn (Polle et al., 1978; Rincón \& Gonzalez, 1992; Cançado, 1999; Giaveno \& Miranda Filho, 1999) and eriochrome cyanine (Aniol, 1995; Ma et al., 1997) and molecular markers (Brondani 
\& Paiva, 1996; Torres et al., 1997). However, genotypes selected by either of the above mentioned methods must be evaluated under field conditions to assure an outstanding pattern of yield in the farms. The purpose of this work was to compare two methodologies of selection for tolerance to acid soil conditions: pots with acid soil and nutrient solution with toxic aluminum.

\section{MATERIAL AND METHODS}

Following the objective of introducing genes for aluminum tolerance, the local population ESALQPB2-3A (50\% ESALQ PB2 and 50\% ESALQ PB3; yellow endosperm) was crossed with the exotic variety SIKUANI ICA V-110, resulting the population SIKALQ considered as the base $\left(\mathrm{C}_{0}\right)$ population.

Individual seedlings of the SIKALQ population were grown in a greenhouse for seven days in nutrient solution of $\mathrm{pH} 4.2$ and $5 \mathrm{ppm}$ of aluminum, as described by Furlani \& Furlani (1988); total number of plants was 1,760 , representing 1,720 of SIKALQ, 20 of sensitive check and 20 of tolerant check. In the SIKALQ population, seedlings with similar length of the principal root were grouped and the secondary roots were eliminated by hand. The length of the principal root was measured to obtain the IRL (initial root length) value. Seedlings were fixed on plastic covers. After seven days, seedlings were removed from the nutrient solution and the FRL (final length of the principal root) value of each plant was measured. NRG (net root growth) for individual plants was obtained by difference (FRL - IRL).

The number of seedlings used was the same as in the screening in nutrient solution. A set of twenty germinating seedlings with the principal root 3 to $5 \mathrm{~mm}$ long was placed into 6.75 I plastic pots filled with acid soil (50\% aluminum saturation) and irrigated with deionized water in a greenhouse. After 15 days, seedlings were pulled from the pots, washed with tap water and then evaluated by visual scoring for whole plant development. Visual scoring was based on a scale of 1 (very poor) to 5 (excellent), considering mainly the size of the root and the shoots.

One cycle of divergent selection was completed by selecting the $10 \%$ most tolerant and $10 \%$ most sensitive seedlings in each methodology. Selected seedlings of four groups were transplanted to the field and randomly crossed in isolated blocks to obtain cycle-
I sub-populations, designated by $\mathrm{C}$-ATNS (Al-tolerant) and $\mathrm{C}_{-}$-ASNS (Al sensitive) and C-ATAS (Al-tolerant) and $\mathrm{C}_{1}$-ASAS (Al sensitive) for selection in nutrient solution and acid soil respectively.

In the field trials the four selected subpopulations were compared to the $C_{0}$ population to measure the effect of the two selection processes utilized in the screening. The local population ESALQPB2-3A was included to measure the effect of the introgressive mating . Two contrasting commercial hybrids were utilized as checks: DINA 766 (tolerant) and MITLA 9560 (sensitive).

These materials were evaluated in the field at two planting dates, early (spring: October) and late (fall: March) at four locations with varying degrees with aluminum saturation (Table 1). A randomized complete block design was used with four replications at each site. Two row plots $4 \mathrm{~m}$ long and spaced $0.90 \mathrm{~m}$ apart were used; planting was in excess to assure 40 plants per plot $\left(55,500\right.$ plants $\left.\mathrm{ha}^{-1}\right)$ after thinning.

The following variables were analyzed: net yield (NY), plant height (PH) and days to male flowering (DF).

All plants in a plot were harvested by hand and grain weight (yield) was adjusted to a standard $14 \%$ of moisture. Because the occurrence of plant lodging, especially in the late planting date (data not shown), grain yield was evaluated as NY. This variable was estimated as the difference between grain yield and the losses produced by lodging. $\mathrm{PH}$ was obtained by measuring the distance $(\mathrm{cm})$ between the ground and the first branch (lower) of the tassel in all plants of the plot. DF was measured as number of days between germination of seedlings and $50 \%$ of the plants in the anthesis stage (pollen release).

For the comparison among locations, a statistical model with population $\mathrm{x}$ environment effects was used:

$$
Y_{i j k}=m+p_{i}+s_{j}+(p s)_{i j}+e_{i j k}
$$

where: $Y_{i j k}$ is the observation of the $Y$ variable, representing the $k^{\text {th }}$ replication of the $i^{\text {th }}$ population at the $j^{\text {th }}$ environment; $m$ is the general mean; $p_{i}$ is the population effect; $s_{i}$ is the effect of location, $(p s)_{i i}$ is the interaction between populations and environments; and $\mathrm{e}_{\mathrm{ijk}}$ is the experimental error. Both populations and environments were taken as fixed effects.

Table 1 - Characteristics of the soils used in the field trials.

\begin{tabular}{ccccc}
\hline Planting date & Productivity & Soil Characteristics & Location \\
\hline Early (spring) & High & no-aluminum soil, N,P,K fertilized and irrigated & Piracicaba. SP \\
& Intermediate high $\mathrm{pH}$ surface correction with lime and fertilization with N,P and K & Anhumas. SP \\
& Intermediate low & $35 \%$ aluminum saturation and $12 \mathrm{ppm}$ of phosphorous. & Anhumas. SP \\
& Low & $45 \%$ aluminum saturation and $8 \mathrm{ppm}$ of phosphorous. & Pindamonhangaba. SP \\
Late ( Fall ) & Low & $53 \%$ aluminum saturation and 9 ppm of phosphorous. & Sete Lagoas. MG \\
\hline
\end{tabular}

*High, intermediate high and intermediate low locations were the same used in the early planting date. 


\section{RESULTS AND DISCUSSION}

The excellent climatic conditions in the early planting date, characterized by high temperature and radiation, resulted in good levels for NY in all locations, including the location with high aluminum saturation, specially when compared with NY observed for the late planting date. Within each planting date, important alterations of net NY were observed (Table 2) when the level of aluminum stress and mineral deficiency increased.

For the trials carried out in Piracicaba, SP (high productivity location), for both planting dates, non statistically significant differences in NY were observed among populations, suggesting that aluminum tolerance in maize was not closely related to low productivity in non acid soils in agreement with Duncan \& Baligar (1987). In these trials, as expected, the best NY was observed in the commercial hybrids used as checks, because these materials were selected to make good use of the high nutritional and climatic conditions.

The high temperature and radiation in the spring were responsible for the good use of the optimal nutritional status and thus the enhancement of NY for about 30 percent in relation to the late planting date. The reduction of the grain yield in maize due to the delay of the planting date for environmental conditions with low irradiation and temperature was reported by several authors (Duncan et al., 1973; Tollenaar et al., 1992) and could be explained by the reduction in the kernel number per ear (Cirilo \& Andrade, 1994) or in the number of ears per plant (Andrade et al., 1996). A higher incidence of leaf diseases has been reported in late (off-season) plantings, which may contribute to lower yield potential under such environmental conditions (Pereira, 1995).

For locations characterized by intermediate to high productivity, the differences between the local population ESALQ PB2-3A and SIKALQ were evident
(Table 4). For both planting dates, the population resulted from the introgressive mating was superior as compared to the local population. A similar situation was observed for the selected sub-populations and the effect of the divergent selection was evident.

Under worse growing conditions due to the increase of aluminum saturation and decrease of soil nutritional conditions, significant differences were observed among populations. In locations characterized by low productivity at both planting dates, the NY of Altolerant sub-population was higher than the Al-sensitive sub-population confirming the effect of the divergent selection processes. The NY of sub-population selected in pots with acid soil was higher than the selected in nutrient solution. Our results show a small advantage of the sub-population selected in pots with acid soil. However, the differences were not statistically significant for locations with intermediate low and low productivity. These results could be explained based on two facts: first, in acid soils, aluminum toxicity was not the only limiting factor. Other chemical and physical factors, as phosphorus and calcium deficiency and the toxicity produced by the excess of manganese, could also have affected grain yield. All of these factors are considered in the selection for pots with acid soil and not necessarily in nutrient solution. Second, the release of organic acid by the roots, induced by the presence of aluminum, was reported as a tolerance mechanism in several crops (Delhaize et al., 1993; Miyasaka et al., 1991; Kochian, 1995) and maize (Pellet et al., 1995). When the selection was based on nutrient solution, organic acid release occurred into the growth media and therefore this approach would not present any advantage for this kind of tolerance. Nevertheless, the NY showed by Al-tolerant sub-population was considered good and this technique is a useful approach, easy and quick, to select maize Al-tolerant genotypes.

Table 2 - Observed means for net yield at two planting dates and locations representing four productivity levels.

\begin{tabular}{|c|c|c|c|c|c|c|c|c|}
\hline \multirow[b]{2}{*}{ Population } & \multicolumn{4}{|c|}{ Early ( Spring) } & \multicolumn{4}{|c|}{ Late ( Fall ) } \\
\hline & $\mathrm{H}$ ns & $\mathrm{IH}^{*}$ & $\mathrm{IL}^{*}$ & $L^{*}$ & $\mathrm{H}$ ns & $\mathrm{IH}^{*}$ & $\mathrm{I} \mathrm{L}^{\star *}$ & $L^{*}$ \\
\hline & ------- & ---------- & ------------- & ------------- & $a^{-1}---$ & ------------- & ------------ & ------------ \\
\hline SIKALQ (C0) & 6.53 & $6.31 \mathrm{AB}$ & $3.60 \mathrm{ABC}$ & $3.27 \mathrm{ABC}$ & 4.78 & $2.97 \mathrm{BC}$ & $2.86 \mathrm{BC}$ & $2.77 \mathrm{ABC}$ \\
\hline ESALQ PB2-3A & 6.83 & $5.45 \mathrm{~B}$ & $3.12 \mathrm{BC}$ & $2.13 \mathrm{BC}$ & 4.45 & $2.89 \mathrm{BC}$ & $2.73 \mathrm{C}$ & $2.53 \mathrm{BC}$ \\
\hline $\mathrm{C}_{1}$ ATNS & 7.41 & $6.59 \mathrm{~A}$ & $4.08 \mathrm{AB}$ & $3.65 \mathrm{AB}$ & 4.83 & $3.57 \mathrm{ABC}$ & $3.44 \mathrm{AB}$ & $3.03 \mathrm{ABC}$ \\
\hline $\mathrm{C}_{1}$ ASNS & 7.03 & $6.30 \mathrm{AB}$ & $3.54 \mathrm{ABC}$ & $2.47 \mathrm{AB}$ & 3.83 & $2.92 \mathrm{BC}$ & $2.72 \mathrm{C}$ & $2.53 \mathrm{BC}$ \\
\hline$C_{1}$ ATAS & 6.51 & $6.73 \mathrm{~A}$ & $4.19 \mathrm{AB}$ & $4.04 \mathrm{~A}$ & 5.22 & $3.38 \mathrm{ABC}$ & $3.76 \mathrm{~A}$ & $3.18 \mathrm{AB}$ \\
\hline C-1 ASAS & 7.50 & $6.06 \mathrm{AB}$ & $2.93 \mathrm{C}$ & $2.93 \mathrm{BC}$ & 5.08 & $2.65 \mathrm{C}$ & $2.76 \mathrm{C}$ & $2.29 \mathrm{C}$ \\
\hline TC & 8.81 & $7.12 \mathrm{~A}$ & $4.22 \mathrm{~A}$ & $3.37 \mathrm{C}$ & 6.38 & $3.94 \mathrm{~A}$ & $3.10 \mathrm{BC}$ & $3.50 \mathrm{~A}$ \\
\hline $\mathrm{SC}$ & 8.20 & $6.72 \mathrm{~A}$ & $3.68 \mathrm{ABC}$ & $2.54 \mathrm{C}$ & 5.45 & $3.60 \mathrm{AB}$ & $2.65 \mathrm{C}$ & $2.50 \mathrm{BC}$ \\
\hline Mean & 7.35 & 6.41 & 3.67 & 3.05 & 5.00 & 3.24 & 3.00 & 2.79 \\
\hline CV\% & 17.6 & 10.3 & 17.3 & 17.8 & 19.5 & 17.5 & 13.8 & 20.2 \\
\hline
\end{tabular}

TC and SC: tolerant and sensitive check, respectively.

$\mathrm{H}$, high; $\mathrm{IH}$, intermediate high; IL, intermediate low and low productivity, respectively.

${ }^{*}, * *, n s$ : significant at probability levels of $P<0.05, P<0.01$, and non significant, respectively.

"Duncan's Test: means with the same letter are not significantly different. 
When the results of the field trials were analyzed together (Table 5), highly significant differences were found for environments and populations and the interaction between these effects was not significant.

$\mathrm{PH}$ was affected by the contrasting climatic and soil conditions in the experiments (Table 3). As reported for NY, at all locations $\mathrm{PH}$ decreased as aluminum saturation increased and the nutritional status of the soil decreased. The smallest values of $\mathrm{PH}$ were observed in both experiments for locations of low productivity, at two planting dates. This situation was confirmed in Table 5 , where highly significant differences were observed for locations and genotypes.

When the data of the two planting dates were compared, higher values of $\mathrm{PH}$ were always observed in the experiments planted earlier, as a result of the better climatic conditions present at the beginning of the growing season, except for $\mathrm{PH}$ measured in high productivity environments. In this situation, the observed means for $\mathrm{PH}$ for all populations were lower than those observed at the same location for later planting.

The effect of the introgressive mating was confirmed for all locations. The SIKALQ population showed high $\mathrm{PH}$ as compared to the local population ESALPB2-3A. PH of the Al-tolerant populations was higher than the Al-sensitive, as the aluminum saturation increased.

Another trait strongly affected by the environmental characteristics was DF. As mentioned for $\mathrm{NY}$ and $\mathrm{PH}$, DF increased as the plant growing conditions moved from high to low productivity. Although the lack of evidences of the effect of aluminum toxicity in the DF enlargement, the starvation of other nutrients as nitrogen and phosphorous, that are characteristic of these soils, could explain this fact. For instance, increases of 8 to 11 days in the DF were reported in maize growing under low nitrogen availability (Girardin, et al., 1987; Jacobs \& Pearson, 1991; Uhart \& Andrade, 1995).

Table 3 - Plant height at two planting dates and locations representing four productivity levels.

\begin{tabular}{|c|c|c|c|c|c|c|c|c|}
\hline \multirow[b]{2}{*}{ Population } & \multicolumn{4}{|c|}{ Early (Spring) } & \multicolumn{4}{|c|}{ Late ( Fall ) } \\
\hline & $\mathrm{H}$ ns & $\mathrm{IH}^{*}$ & $I L^{*}$ & $L^{*}$ & $\mathrm{H}$ ns & $\mathrm{IH}^{*}$ & $\mathrm{I} \mathrm{L}^{* *}$ & $L^{*}$ \\
\hline & & 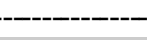 & & ------ & m ------- & & & 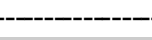 \\
\hline SIKALQ (C0) & $184.8 A^{*}$ & 192.8 AB & 147.5 & 151.1 AB & $210.4 \mathrm{~A}$ & $157.0 \mathrm{~A}$ & 137.8 & 124.6 A \\
\hline ESALQ PB2-3A & $178.5 \mathrm{~A}$ & $186.5 \mathrm{BC}$ & 140.5 & $137.7 \mathrm{BC}$ & 203.7 B & $154.7 \mathrm{AB}$ & 133.4 & 112.4 CD \\
\hline$C_{1}$ ATNS & $177.0 \mathrm{~A}$ & $187.5 \mathrm{BC}$ & 153.4 & 152.7 BC & $213.8 \mathrm{~A}$ & 153.9 ABC & 136.0 & $122.4 \mathrm{~A}$ \\
\hline$C_{1}$ ASNS & $183.6 \mathrm{~A}$ & $182.7 \mathrm{C}$ & 143.8 & $139.2 \mathrm{C}$ & $214.9 \mathrm{~A}$ & $149.4 \mathrm{C}$ & 133.6 & $112.9 \mathrm{CD}$ \\
\hline $\mathrm{C}_{1}$ ATAS & $181.8 \mathrm{~A}$ & $195.3 \mathrm{~A}$ & 155.1 & $151.3 \mathrm{~A}$ & $212.5 \mathrm{~A}$ & $155.5 \mathrm{AB}$ & 141.9 & 120.6 AB \\
\hline$C_{1}$ ASAS & $178.8 \mathrm{~A}$ & $184.7 \mathrm{C}$ & 151.1 & $142.5 \mathrm{C}$ & $199.2 \mathrm{~B}$ & $150.7 \mathrm{BC}$ & 136.7 & $104.4 \mathrm{E}$ \\
\hline TC & $174.5 \mathrm{~A}$ & 186.7 BC & 144.4 & $133.8 \mathrm{~B}$ & $211.1 \mathrm{~A}$ & 152.1 ABC & 140.8 & $114.7 \mathrm{BC}$ \\
\hline SC & $176.0 \mathrm{~A}$ & 185.3 BC & 138.9 & $124.9 \mathrm{~B}$ & $210.8 \mathrm{~A}$ & 144.6 D & 127.1 & 106.5 DE \\
\hline Mean & 179.4 & 187.7 & 146.8 & 141.7 & 209.6 & 152.2 & 135.9 & 114.8 \\
\hline CV\% & 10.3 & 6.1 & 9.2 & 12.3 & 12.0 & 19.6 & 21.9 & 9.4 \\
\hline
\end{tabular}

TC and SC: tolerant and sensitive check, respectively.

$\mathrm{H}$, high; $\mathrm{IH}$, intermediate high; IL, intermediate low and low productivity, respectively.

${ }^{*},{ }^{* *},{ }^{n s}$ : significant at probability levels of $\mathrm{P}<0.05, \mathrm{P}<0.01$, and non significant, respectively.

"Duncan's Test: means with the same letter are not significantly different.

Table 4 - Days to male flowering at two planting dates and locations representing four productivity levels.

\begin{tabular}{|c|c|c|c|c|c|c|c|c|}
\hline \multirow[b]{2}{*}{ Population } & \multicolumn{4}{|c|}{ Early ( Spring) } & \multicolumn{4}{|c|}{ Late ( Fall ) } \\
\hline & $\mathrm{H}$ ns & $\mathrm{IH}^{*}$ & $I L^{*}$ & $L^{*}$ & $\mathrm{H}$ ns & $\mathrm{IH}^{*}$ & $I L^{* *}$ & $L^{*}$ \\
\hline$\overline{S I K A L Q}(\mathrm{CO})$ & $49.7 \mathrm{C}$ & $50.5 \mathrm{~B}$ & $57.0 \mathrm{~A}$ & $64.0 \mathrm{C}$ & $52.0 \mathrm{C}$ & $53.5 \mathrm{C}$ & $58.0 \mathrm{E}$ & $71.0 \mathrm{C}$ \\
\hline ESALQ PB2-3A & $53.7 \mathrm{~A}$ & $55.0 \mathrm{~A}$ & $61.0 \mathrm{~A}$ & $68.2 \mathrm{~A}$ & $55.0 \mathrm{~A}$ & $55.5 \mathrm{~A}$ & $62.0 \mathrm{~A}$ & $77.0 \mathrm{~A}$ \\
\hline$C_{1}$ ATNS & $51.0 \mathrm{BC}$ & $52.5 \mathrm{~B}$ & $56.0 \mathrm{~A}$ & $63.7 \mathrm{C}$ & $52.5 \mathrm{BC}$ & $53.0 \mathrm{D}$ & $58.0 \mathrm{E}$ & $71.0 \mathrm{C}$ \\
\hline $\mathrm{C}_{1}$ ASNS & $52.0 \mathrm{AB}$ & $52.5 \mathrm{~B}$ & $57.5 \mathrm{AB}$ & $65.5 \mathrm{~B}$ & $52.7 \mathrm{BC}$ & $54.0 \mathrm{C}$ & $58.5 \mathrm{D}$ & $73.0 \mathrm{~B}$ \\
\hline$C_{1}$ ATAS & $51.5 \mathrm{BC}$ & $52.2 \mathrm{~B}$ & $56.5 \mathrm{~B}$ & $63.5 \mathrm{C}$ & $53.0 \mathrm{~B}$ & $54.5 \mathrm{~B}$ & $58.5 \mathrm{D}$ & $72.0 \mathrm{BC}$ \\
\hline C-1 ASAS & $51.2 \mathrm{BC}$ & $52.5 \mathrm{~B}$ & $58.0 \mathrm{AB}$ & $66.0 \mathrm{~B}$ & $52.5 \mathrm{BC}$ & $54.0 \mathrm{C}$ & $59.0 \mathrm{C}$ & $73.0 \mathrm{~B}$ \\
\hline $\mathrm{TC}$ & $50.0 \mathrm{BC}$ & $50.5 \mathrm{~B}$ & $56.0 \mathrm{~A}$ & $64.0 \mathrm{C}$ & $52.0 \mathrm{C}$ & $53.5 \mathrm{C}$ & $58.0 \mathrm{E}$ & $71.0 \mathrm{C}$ \\
\hline SC & $51.2 \mathrm{BC}$ & $52.0 \mathrm{~B}$ & $57.7 \mathrm{AB}$ & $66.0 \mathrm{~B}$ & $53.0 \mathrm{~B}$ & $54.0 \mathrm{C}$ & $60.0 \mathrm{~B}$ & $73.0 \mathrm{~B}$ \\
\hline Mean & 51.3 & 52.2 & 57.5 & 56.6 & 52.8 & 54.0 & 59.0 & 72.6 \\
\hline CV\% & 2.38 & 2.32 & 3.86 & 3.71 & - & 0.54 & 0.45 & 0.93 \\
\hline
\end{tabular}

TC and SC: tolerant and sensitive check, respectively.

$\mathrm{H}$, high; $\mathrm{IH}$, intermediate high; IL, intermediate low and low productivity, respectively.

*, ${ }^{* *}$, ns : significant at probability levels of $P<0.05, P<0.01$, and non significant, respectively.

"Duncan's Test: means with the same letter are not significantly different. 
Table 5 - Analysis of variance for three variables measured for eight populations in eight environments.

\begin{tabular}{lrrrr}
\hline & df & \multicolumn{3}{c}{ Mean squares } \\
\hline Source of variation & & NY & PH & \multicolumn{1}{c}{ DF } \\
Blocks / Locations & 24 & $0.7^{\text {ns }}$ & $2.0^{* *}$ & $4.81^{* *}$ \\
Locations & 7 & $110.7^{* *}$ & $267.2^{* *}$ & $1772.15^{* *}$ \\
Genotypes & 7 & $9.3^{* *}$ & $4.2^{* *}$ & $37.35^{* *}$ \\
Genotypes x Locations & 49 & $1.1^{\text {ns }}$ & $0.7^{\text {ns }}$ & $5.42^{* *}$ \\
Error & 168 & & &
\end{tabular}

NY, net yield; L, lodging; $\mathrm{PH}$, plant height and DF, time of flowering. ${ }^{*},{ }^{* *},{ }^{n s}$ : significant at probability levels of $\mathrm{P}<0.05, \mathrm{P}<0.01$, and non significant, respectively.

The effect of phosphorous starvation in the enlargement of the DF was less studied than nitrogen. However, Spence and Welch (1977) cited by Andrade et al. (1996) reported an important DF enlargement as phosphorous deficiency increased.

A similar situation was observed when two planting dates were compared. In locations of later plantings, DF for all genotypes was higher than the observed for early planting. This enlargement of DF could be explained based on the strong influence of the temperature in completing the developmental stages (Andrade et al.,1996).

In the combined analysis, high differences were observed for locations, genotypes and interaction.

Both selection procedures were effective for the screening of maize seedlings for aluminum tolerance, and in spite of little differences, the selection in pots with acid soil was more efficient than in nutrient solution.

\section{ACKNOWLEDGMENTS}

To Dr. Sidney Parentoni, CNPMS - EMBRAPA and Dr. Omar Vilela, IAC, for their help in conducting the field experiments. Research and publication supported were by FAPESP.

\section{REFERENCES}

AHLRICHS, J.L.; KARR, M.C.; BALIGAR, V.C.; WRIGHT, R.J. Rapid bioassay of aluminum toxicity in soil. Plant and Soil, v.122, p.227-285, 1990.

ANDRADE, F.H.; CIRILO, A.G.; UHART, S.A.; OTEGUI, M.E. Ecofisiología del cultivo de maíz. Balcarce: Dekalpress, 1996. 289p.

ANIOL, A. Induction of aluminum tolerance in wheat seedlings by low doses of aluminum in nutrient solution. Plant Physiology, v.75, p.551-555, 1984

BRONDANI, C.; PAIVA, E. Análise de RFLP da tolerância a toxidez do alumínio no cromossomo 2 do milho. Pesquisa Agropecuária Brasileira, v.31, p.575-579, 1996 .

CANCCADO, G.M.A.; LOGUERCIO, L.L.; MARTINS, P.R.; PARENTONI, S.N.; PAIVA, E.; BOREM, A.; LOPES, M.A. Hematoxylin staining as a phenotypic index for aluminum tolerance selection in tropical maize (Zea mays $\mathrm{L}$.) Theoretical and Applied Genetics, v.99, p.747-754, 1999.

CIRILO, A.G.; ANDRADE, F.H. Sowing date and maize productivity: II. Kernel number determination. Crop Science, v.34, p.1044-1046, 1994.
DELHAIZE, E.; CRAIG, S.; BEATON, C; BENNET, R.J.; JAGANDISH, V.C.; RANDALL, P.J. Aluminum tolerance in wheat (Triticum aestivum L.). I. Uptake and distribution of aluminum in root apices. Plant Physiology, v.103, p.685-693, 1993

DUNCAN, R.R.; BALIGAR, V.C. Genetics, breeding and physiological mechanisms of nutrient uptake and use efficiency an overview. In. BALIGAR, V.C.; R.R. DUNCAN (Ed.) Crop as enhancers of nutrient use. San Diego: Academic Press, 1990. p.3-35.

DUNCAN, R.R.; CLARK, R.B.; FURLANI, P.R. Laboratory and field evaluations of sorghum for aluminum and acid soil. Agronomy Journal, v.75, p.10231026, 1983.

FURLANI, A.M.C.; FURLANI, P.R. Composição e pH de soluções nutritivas para estudos fisiológicos e seleção de plantas em condições nutricionais adversas. Campinas: IAC, 1988. p.1-34. (Boletim Técnico, 121)

GIAVENO C.D.; MIRANDA FILHO, J.B. Visual detection of aluminum tolerance in maize (Zea mays L.) Genetics and Molecular Biology, v.22, p.677, 1999. Supplement.

GIAVENO C.D.; MIRANDA FILHO, J.B.; FURLANI, P.R. Tolerância ao alumínio em milho (Zea mays L.): seleção divergente em solução nutritiva. Genetics and Molecular Biology, v.21, p.242, 1998. Supplement.

GIRARDIN, P.; TOLLENAAR, M.; DELTOUR, A.; MULDOON, J. Temporary N starvation in maize (Zea mays L.): effects on development, dry matter accumulation and grain yield. Agronomie, v.7, p.289-296, 1987.

JACOBS, B.C.; PEARSON, C.J. Potential yield of maize determined by rates of growth and development of ears. Field Crops Research, v.27, p.281289, 1991

KOCHIAN, L.V. Cellular mechanisms of aluminum toxicity and resistance in plants. Annual Review of Plant Physiology, v.46, p.237-260, 1995.

LIMA, M.; FURLANI, P.R.; and MIRANDA FILHO, J.B. Divergent selection for aluminum tolerance in a maize (Zea mays L.) population. Maydica, v.37, p.123-132, 1992.

MA, J.F.; ZHENG, S.J.; LI, X.F.; TAKEDA, K.; MATSUMOTO, H.A. Rapid hydroponic screening for aluminum tolerance in barley. Plant and Soil, V.191, P.133-137, 1997.

MAGNAVACA, R.; GARDNER, C.O.; CLARK, R.B. Inheritance of aluminum tolerance in maize. In GABELMAN, H.W.; LOUGHMAN, B.C. (Ed.) Genetics aspects of plant mineral nutrition. Dordrechit: Martinus Nijhoff, 1987. p.201-212.

MIYASAKA, S.C.; KOCHIAN, L.V.; SLAFF, J.E.; FOY, C.D. Mechanism of aluminum tolerance in wheat. An investigation of genotipyc differences in rhizosphere $\mathrm{pH}, \mathrm{K}+$ and $\mathrm{H}+$ transport, and root cell membranes potentials. Plant Physiology, v.91, p.1188-1196, 1989

MORO, J.R. Melhoramento - Tendências atuais. In: OSUNA, J.A.; MORO, J.R. (Ed.) Produção e melhoramento de milho. Jaboticabal: FUNEP, 1995. p. 109-117.

PANDEY, S.; CEBALLOS, H.; GRANADOS, G.; KNAPP, E. Developing maize that tolerates aluminum toxic soils. In: C.I.M.M.Y.T. Stress tolerance breeding: Maize that resist insects, drought, low nitrogen and acids soils. México, 1994a. p. 85-93

PELLET, D.M.; GRUNES, D.L.; KOCHIAN, L.V. Organic acid exudation as an aluminum-tolerance mechanism in maize (Zea mays L.) Planta, v.196, p.788-795, 1995.

PEREIRA, O.A.P. Situação atual de doenças da cultura do milho no Brasil e estratégias de controle. Temas de Genética e Melhoramento, v.12, p.2530, 1995.

POLLE, E.; KONZAK, C.F.; KITTRICK, J.A. Visual detection of aluminum tolerance levels in wheat by hematoxilyn staining of seedling roots. Crop Science, v.18, p.823-827, 1978

RINCÓN, M.; GONZALEZ, R.A. Aluminum partitioning in intact roots of aluminum-tolerant and aluminum-sensitive wheat (Triticum aestivum L.) cultivars. Plant Physiology, v.99, p.1021-1028. 1992.

TOLLENAAR, M.; DWYER, L.M.; STEWART, D.W. Ear and kernel formation in maize hybrids representing three decades of grain yield improvement in Ontario. Crop Science, v.32, p.432-438, 1992.

UHART, S.A.; ANDRADE, F.H. Nitrogen deficiency in maize: I. Effects on crop growth, development, dry matter partitioning and kernel set. Crop Science, v.35, p.1376-1383, 1995.

URREA GÓMEZ, R.; CEBALLOS. E.; PANDEY, S.; BAHÍA FILHO, A.F.C. LEÓN, L.A. A greenhouse screening technique for acid soil tolerance in maize. Agronomy Journal, v.88, p.806-812, 1996.

Received June 05, 2001 